\title{
The role of David in the composition and redactional grouping of the final davidic Psalter
}

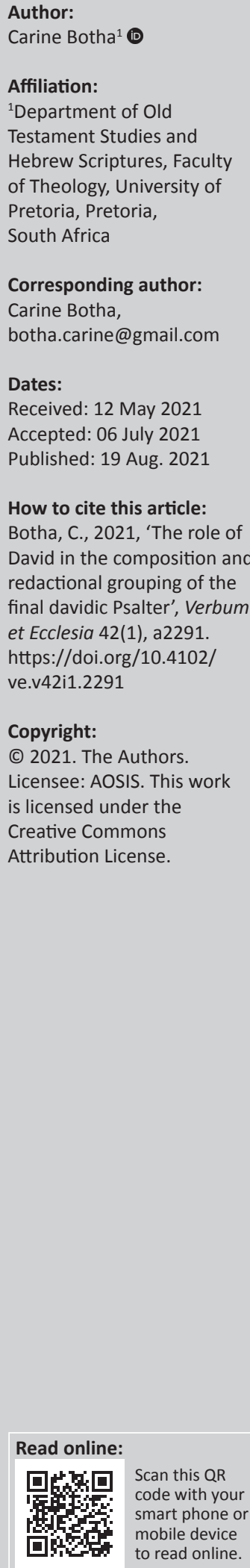

Superscripts in the Psalter have been disregarded as later editorial additions to the text. However true, superscripts provided insight into the editorial rationale behind the Psalter. Despite almost complete absence in Book IV, David's presence resurfaced in Book V, through davidic superscripts. The last bearers of the davidic superscript, Psalms 138-145, posed the question: How does the reference to David in the headings aided our interpretation of these psalms? A redaction-historical approach to the interpretation of Psalms 138-145 illustrated how davidic superscripts aided to demonstrate David's exemplification as priest-king who displayed an attitude of dependence on YHWH's protection. This article reflects on the final davidic Psalter through considering the redactional rationale of contributing Psalms 138-145 to David. Reflections on David's theological significance in Book V of the Psalter is suggested. This study resulted in the implication that David as king now submitted to a greater King than himself.

Intradisciplinary and/or interdisciplinary implications: This article challenged a form-critical approach to psalms signifying that any study of a psalm must be context-comprehensive. By applying a redactional critical method to the final davidic Psalter, this study emphasised the theological significance of the use of superscripts. This study called for the entire editorial process that resulted in the Psalter (as we have it today) to be considered when studying psalms, also highlighting the need for psalms to be studied in their editorial contexts.

Keywords: Psalms 138-145; final davidic Psalter; davidic superscripts; Book V; Psalter; Psalms.

\section{Introduction}

It is important to note from the outset that davidic superscripts do not necessarily imply davidic authorship. Superscripts in the Psalter have long been the subject of disagreement amongst scholars. Owing to its later addition to the psalms, some scholars disregard its hermeneutical importance. Nevertheless, an argument can be made that within a redactional framework, psalm titles serve as reasonable guidelines to discern groups and collections of psalms in the Psalter (Longman 2014:24). Although psalm titles were not assigned by the original authors/composers of the psalms and they were most likely only added before the end of the canonical period, it remains the work of an editor. Therefore, although psalm titles were not part of the original compositions, they provide meaningful insight into the editorial process to which the Psalter was subjected as well as the redactional narrative intended to be conveyed. Psalm titles remain vital in comprehending the Psalter in its final form (Ramantswana 2011:438).

How then should we understand the David of the psalms? Are the psalms attributed to him the product of the historical David? Or are the psalms perhaps reflective of the historical events in the life of David? Mays (1986:155) pointed out that there is an undeniable association of David with the psalms throughout the Old Testament, the hermeneutical effects of which cannot be refuted. It is argued by some that the psalms containing the phrase לדוד (for/of David) originally belonged to a collection of psalms that were originally authored by David (Fraser 1984:46). With the editing of the Psalter, it is believed that these psalms were selectively placed in the five books to support the narrative and/or theological message of the Psalter. According to Nogalski (2001:169), the connections made to David and the historical events in the life of David are only made to substantiate the narrative of the Psalter at its various stages, rendering the narrative of the Psalter and the character of David more suitable for use in communal worship. This point of view reduces David to nothing more than a model for worship. Rentdorff (2005:53) reckoned that the question at hand should rather be What kind of David is portrayed in the Psalter? He continues to answer this question with three 'types' of David that is displayed throughout the Psalter: the anointed David, the messianic David, and the refugee David. This point of view renders David nothing more than a beacon of hope in God, reducing the theological importance 
of the Psalter to just as much. Jung (2016:3) illustrated that the David of the Psalter is not the historical figure, but rather a literary character that assumes different personas throughout its narrative. According to Jung, David is a 'literary speaker as part of the literary world of the psalms'. This viewpoint portrays David as the identifiable character of the Psalter to which readers can relate throughout their trials and victories. Through renditions of persecution and fortification, the character of David becomes more than a figure of hope. In fact, he becomes a role model and exemplar in faith.

The final davidic Psalter consists of a collection of psalms grouped by a superscript that connects these eight psalms to the same designated author and/or character. Without exception, all eight psalms in the fifth and final davidic Psalter contain the phrase לדוד (for/of David). Yet, this is not the only psalms in Book $\mathrm{V}$ to contain davidic designations. Other psalms that are attributed to David in Book V include Psalms 108-110, 122, 124, 131 and 133. To encounter the name of David in the psalms is, at the very least, anticipated. Of the 116 psalms that contain superscripts, 73 of them are assigned to David, making David the 'favourite figure' (Ramantswana 2011:455) of the entire Psalter. It can be said that the regulating factor in the editing of the Psalter is nothing other than the character of David. To encounter David in Book V is, however, odd. To fully comprehend the peculiarity of David's resurgence in Book V of the Psalter, it will be benefitting to start with the characters/personas that David assumes in the redaction of the Psalter.

\section{David in Book V of the Psalter}

Assisting the reader in navigating the editorial purpose and consequently the narrative of the Psalter is the 'royal psalms' (Ps 2, 72, 89), which was resolutely placed at the seams of the first three books (Wilson 1986:85-91). It is argued, based on the presence of these 'royal psalms', that the Psalter can be divided into two main segments. The first segment consists of Psalms 2-89. Psalm 2 introduces this segment by referencing the establishment of the davidic covenant (Wilson 2005:391) and continues by celebrating the davidic covenant (2 Sm 7) and the divine support that sustained it. In the first and second books, David features prominently as the vessel through which YHWH's covenant is realised for all of Israel. The persona David assumes is that of the righteous king (Jung 2016:61). Book II closes with the Solomonic psalm stating that: 'This concludes the prayers of David son of Jesse' (Ps 72:20). David is no more. Nevertheless, the blessing that comes through the davidic covenant continues through David's descendant, that is, Solomon (2 Sm 7:12). In Book III, there is a drastic change in tone. The kingdom that once flourished under the blessings of the davidic covenant is torn apart and suffers oppression, which culminates in exile. The persona that David (or the davidic descendant) assumes here is that of the defender of the impoverished and the destitute (Jung 2016:100). The first segment of the Psalter is closed with criticism against YHWH for the collapse of the davidic kingdom (Ps 89:39-46) and an appeal to YHWH to remain faithful to the house of David (Ps 89:48-52). Here, we encounter the end of what was the davidic empire. It should be noted that Books I-III do not represent the reader of the Psalter with a historical retrospective. Instead, it should be understood as an exilic collection, written with the purpose to cultivate hope for the re-establishment of the davidic kingdom (Wilson 2005:393).

The second segment of the Psalter does not consist of any 'royal psalms' at its seams. By inference, the celebration of all that is David and the empire he has built has come to an abrupt end. An end riddled with uncertainties and questions. The יהוה מלך. (YHWH reigns) psalms in Book IV, which includes Psalms 93 and 95-99, indicates an alteration in focus away from human kingship to the kingship of YHWH (Wilson 2005:392). What is more is the fact that Book IV is riddled with Mosaic and Exodus themes (Tate 1990:452453). Amidst their uncertain situation, the exilic community grabs hold of something that predates the davidic covenant. This substantiates the theory that the nation that once rejected YHWH as their King (1 Sm 8:7) and demanded an earthly king (1 Sm 8:19) - the same nation that did not heed the prophet Samuel's warnings about the fallibility of earthly kingship - now once again put their confidence in the Sinaitic covenant, which is first and foremost defined by the Torah. In Book IV, a reversion and revaluation of kingship and covenant are perceptible.

Despite the almost complete absence of David in Book IV, David's presence resurfaces in Book V. Of the 44 psalms comprising this book, 15 exhibit davidic superscripts. Furthermore, Psalm 132 focuses on the davidic kingship and monarchy; the heading of Psalm 142 refers to a historical event in the early days of David's life, and David is also found in the corpus of Psalm 144. The magnitude of David's presence in Book $\mathrm{V}$ raises the question: What does the recurrence of David, in the concluding chapters of the canonical Psalter, intend to convey?

A closer look at David's resurgence in Book V ultimately reveals the motive.

Psalm 107 points to the dawn of a new day for the people of YHWH. Where the fourth book was dominated by the exile and a reversion back to the Sinaitic covenant, Psalm 107 presents the reader with the end of the exile. The rest of the fifth book follows in shaping the part of the narrative where Israel and Zion are restored.

There are two main collections of davidic psalms in Book V of the Psalter: Psalms 108-110 and Psalms 138-145. Creach (1996:100-101) advised that to understand the two davidic collections in Book V, the psalms foregoing these collections must be taken into consideration, as these collections serve as a response to the concerns raised in the psalms that precede it. In the case of Psalms 108-110, the preceding psalm that needs to be considered is Psalm 107. Psalm 107 opens with the call to praise YHWH. Here, we find a celebration of YHWH's goodness and everlasting love. The psalm concludes by cautioning the wise to keep in mind all the goodness and love 
that YHWH has shown them. Following this counsel is the first davidic corpus in Book V. In Psalms 108-110, which is a 'trilogy of war and renewed honour' as coined by Sutton (2015:22), David is the depicted character that heeds the warning of Psalm 107. In Psalm 108, David is found in a solemn state of mind. We hear his cry: 'Is it not you, God, you who have rejected us and no longer go out with our armies? Give us aid against the enemy, for human help is worthless' (vv. 12 and 13), perhaps an admittance, placed in the mouth of David, to the fallibility of the davidic kingship? Still, amidst his distress, we see David committing to praise YHWH (vv. 1-5). Even during David's revolt against his enemies, in Psalm 109, where David experiences total desolation, he continues in YHWH's praises. Wallace (2014:199) pointed out that although Psalm 109 is filled with imprecatory language, the word [goodness] is used a total of four times (Ps 109:12, 16, 21 and 26). In all the four times, this word is used in a manner that displays YHWH's capacity to grant or withhold goodness. This is crucial for our understanding of how David is portrayed in the final book of the Psalter. David commits to praising $\mathrm{YHWH}$, although $\mathrm{YHWH}$ no longer aids him (Ps 108:12) and chooses to remain silent (Ps 109:1). David's appeals to the goodness of $\mathrm{YHWH}$ is not simply a prayer to be granted kindness and favour, but rather an appeal to YHWH's 'covenantal loyalty' (Wallace 2014:200). Here, David is the voice appealing to the remembrance of the davidic covenant - a time when YHWH fought Israel's battles and YHWH's voice was heard through the prophets.

In Psalm 110, which is a royal psalm, we are faced with what seems to be the reinstatement of David as king, as he is invited to take a seat at YHWH's right hand (v. 1) and later on, YHWH is taking the position on David's right hand leading David in battle and restoring David's honour. Hossfeld and Zenger (2011:539-579) stated that this representation of David should not be regarded as similar to the portrayal of the ideal king in Books I and II of the Psalter. Instead, the depiction of David in Psalm 110 should be understood as a revived version of David - a new David. In support of this notion is the fact that David is no longer depicted as the mighty king he once was. David is no longer referred to by

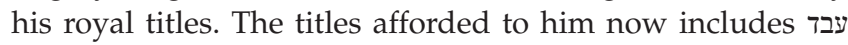
[servant] and משיח [anointed one]. Psalm 110 portrays David as a כהן [priest] in the order of Melchizedek. From the use of these abridged designations, it is clear that a role reversal is taking place in Book V. David now assumes what seems to be a lesser role, but which is the biggest role he is yet to play in this narrative of the Psalter. Where David's kingship was always equated with divine support, now divine kingship is associated with davidic patronage. David becomes the model for an attitude of dependence and trust in YHWH (Howard 1993:52). Although his election is still underlined, his appointment is no longer to a position of power, but rather to a position of servitude. Through this role reversal, David becomes 'the prototypical figure of hope' (Hossfeld \& Zenger 2011:3) for the post-exilic community.

Before we jump to the final davidic Psalter, proper consideration must be given to another royal psalm, that is,
Psalm 132, as it plays a cardinal role in our understanding of what place and purpose David takes on in the fifth book of the Psalter. The collection of šîr hama' ălot psalms (Ps 120-134) of which Psalm 132 forms part of, explains the post-exilic community's pilgrimage from exile (Ps 120) to Zion (Ps 134). This collection was creatively shaped to communicate the post-exilic community's newfound royal and Zion theology, that is, a theology that centres around three themes (Human 2009:68): Jerusalem (Ps 120-124), the temple (Ps 125-129), and David (Ps 130-134). Central to the part of the collection that explains the current place of David (or the davidic lineage) in this royal and Zion theology is Psalm 132. Formcritically, Psalm 132 is divided into two equal parts, in which the first is a petition and the second is a divine reply. From this petition and divine reply, two fundamental ideas arise: Firstly, David has sworn an oath to YHWH (vv. 1-10) and secondly, YHWH has sworn an oath to David (vv. 11-18). Once again, we are reminded of the davidic covenant. The oath that David has sworn to YHWH is narrated as the past and it is called into remembrance. Verse 6 makes note of two geographical locations, which recount the narrative of the time when the Ark of the Covenant was taken from Jerusalem by the Philistines. David came from Ephrata when he heard the news of the capturing of the ark and he set out to bring back the ark from Kiriath-Jearim to Jerusalem (1 Sm 7:1, 2 Sm 6:2) - its rightful place. With this historical event in mind, when the so-called presence of YHWH was stolen from the Israelites, YHWH is now called to return to YHWH's chosen resting place, namely, Zion, in a similar manner. In its second half, Psalm 132 points to the eschatological future (Prinsloo 2005:471) when YHWH is called to remember the promise made to David that one of his descendants will be seated on the Judaic throne עדי־ע] [forever and ever] in verse 12. Although before the psalm concludes with David's descendant's head being adorned with a crown, YHWH takes over the throne and the kingship in verses 13-16. YHWH again chose Zion as a dwelling, stating that 'This is my resting place forever and ever; here I will sit enthroned, for I have desired it' (v. 14). By employing the same adage 'forever and ever' the author asserts divine rulership over davidic kingship. Underscoring this notion is the striking reference made, in both parts of Psalm 132, to the priesthood. In the first half, the desire is expressed for the priesthood of $\mathrm{YHWH}$ to be clothed in righteousness (v. 9), whilst in the second half, the priesthood is clothed with salvation at the hands of YHWH (v. 16).

Barbiero (2013:255) pointed to the importance of $\mathrm{YHWH}$, being the one who is undertaking the clothing of the priesthood, and stated that this action serves to accentuate YHWH's authority and personal intervention on behalf of the people, as is expected from a king. Wilson (2005:397) affirmed that this enthronement of $\mathrm{YHWH}$ is directed towards those who kindled the hope of the resuming davidic kingship over Israel. This declaration is not aimed at diminishing hope in the davidic covenant, but to address the people's disappointment over the failure of the davidic kingship. It aims to turn the people's hope towards divine kingship instead. Patton (1995:652) stated that this time around, with the restoration of Zion and the covenant, $\mathrm{YHWH}^{\prime}$ s presence is 
first established on Zion, before the anointing of the davidic lineage. Where David came first in history, before the sanctuary of YHWH, now YHWH comes first.

Yet, in the final verses of Psalm 132, YHWH promises to 'make a horn grow for David' whose 'head will be adorned with a radiant crown'. Although YHWH resumes the throne and kingship over Israel, David is still bestowed a rank and status. What does this newfound position of David entail? To answer this question, one should note the similar language used in Psalm 110:4 and Psalm 132:11-12. In both instances, an oath is being sworn to David by YHWH. In Psalm 110:4, YHWH swears an oath to David stating that he will forever be a priest in the order of Melchizedek's. Not much is known about this mysterious king of Salem who was also a priest of 'El Elyon' (God Most High). However, Wallace (2014:201) remarked that the mystery of Melchizedek is cleared up when we consider the meaning of his name. The ancient Canaanite name מלכי־צדק can be translated with 'my king is righteous'. Thus, even when assuming this high-clad priestly role, David (or his descendant) would still be positioned as the king. In Psalm 132:11-12, YHWH swears an oath to David that his descendants will remain enthroned in Israel. The oath to the enduring kingship of the davidic dynasty, however, comes with a qualification: 'If your sons keep my covenant and the statutes, I teach them ...' (v. 12). The oath sworn to David is twofold - an oath of both priesthood and kingship (Routledge 2009:1-16) - with the requirement of faithfulness to the Torah. It is evident that the entrance of YHWH into the temple will result in the proper restoration of the priesthood as well as the kingship and obedience to the law. It is made clear that the descendant of David would be, not a king, but very precisely a priest-king (Jr 33:17; Zch 6:13-14). Mitchell (2006:533) pointed out that, although YHWH assumes the role of kingship in Psalm 132, it does not by any means diminish David's role. The kingship of David is portrayed in an even loftier way, by relating David to the role of the priesthood and more precisely his 'Genesis antitype', the priest-king Melchizedek. This newfound role/title of David promotes him to the position of being seated on YHWH's right hand (Ps 110:1). At its core, Psalm 132 is a psalm about place and position. It not only describes the place and position that YHWH holds in the post-exilic community but also the new place and position that the davidic lineage is to assume in this novel paradigm.

From this exposition, we can conclude that the hypothesis of Wilson (2005:392) that divine kingship comes to the fore in Books IV and V carries weight. In Book V, there is a definite sense of YHWH's Kingship being reaffirmed over Israel. However, we have to disagree with Wilson that David is portrayed in a lesser manner to the effect that he becomes nothing but a meek supplicant. A brief overview of the psalms connected to David in Book V demonstrates quite the opposite. In Book V, David is portrayed as a new kind of kinga priest-king who uses his enemies as a footstool (Ps 110:1) and who is exalted to the honourable position of sitting at YHWH's right hand.

\section{David in the final davidic Psalter}

As Book V, and the whole of the Psalter for that matter, comes to a close, we are met with David's final appearance. Psalms 138-145 are the last bearers of the davidic superscript. As already noted, these assigned superscripts should not be passed by as mere editorial additions but should be regarded as a helpful tool to discern the rationale of the pairing as well as the positioning of these so-called 'Psalms of David' (Burden \& Prinsloo 1987:16). We are to ask: How does the reference to David in the headings of Psalm 138-145 aid our interpretation of these psalms?

Once again, following Creach's (1996:101) counsel, the concerns raised in Psalm 137 should be considered to understand the response of Psalms 138-145. Psalm 137 serves as a 'bridge text' (Zenger 2008:365) to the final davidic Psalter. Thanks to popular culture and the creative adaptation of Psalm 137 by the Melodians in 1970, the concerns raised in Psalm 137 is well-known. Although contrary to the goodspirited tune it is set to, it is a psalm that recalls the exile and the dire suppression the Judeans faced in a land where they lived as captives. Psalm 137 relates the people's feelings of displacement (Ahn 2008:268) and their remembrance of Zion whilst far away from it. Psalm 137 contemplates the question of 'being' amidst circumstances where the Judeans were stripped of everything that contributed to the formation of their identity. The sentiments of this contemplation are summed up in the words of verse 4: 'How can we sing the songs of the Lord while in a foreign land?' The Babylonians demanded songs of שםחה [joy] - in other words, songs of praise. Praise songs are the kind of songs that can only be sung when in YHWH's presence. Being in a foreign land, far away from Zion/Jerusalem (and thus far away from YHWH's presence), makes the requested song an impossible one to perform (Berlin 2005:68). Answering the great concern raised in Psalm 137 is Psalm 138. Via superscripts, this psalm and the seven psalms that follow are placed in the mouth of David. In the introduction to the final davidic Psalter, David responds with the words: 'I will praise you, Lord, with all my heart; before the gods, I will sing your praise' (Ps 138:1).

Van Grol (2010:311-313) suggested that the headings of Psalms 138-145 are indicative for an interpretation of the last group of psalms assigned to David, and what these psalms articulate about David and YHWH. Using the headings as a point of departure, it becomes clear that all the headings, except for Psalms 142 and 145, find their parallel in the other books of the Psalter. The headings of Psalms 138 and 144 are paralleled in Psalms 25-28, 35, 37 and 103; the heading of Psalm 139 is paralleled in Psalms 40 and 109; the heading of Psalm 140 is paralleled in Psalms 13, 19-21, 31, 41, 51 and 64; the headings of Psalms 141 and 143 are paralleled in Psalms 15, 23 and 29 (Van Grol 2010:311). Because of the exceptionality of its heading, attention is foremost directed towards Psalm 142. Psalm 142 is introduced with the heading: 'Maskil of David when he was in the cave, a prayer'. Two terms attract attention: משכיל (masekil) and תפלה $\left(\underline{t}^{e} \bar{p} i l l \bar{a}\right)$. Although initially associated with David (in Ps 32), 
the term mas ${ }^{e} k \hat{l} l$ subsequently became associated with other authors, such as the Korahites (Ps 42, 44, 45), Asaph (Ps 74, 78), and Herman (Ps 88, 89). It is striking that the use of the term mas $^{e} k \hat{\imath} l$ only occurs in the first three books of the Psalter. Therefore, Van Grol (2010:312) insisted that attributing this musical term that conveys musical performance (Amzallag \& Yona 2016:52) to David in Psalm 142 is the equivalent of assigning it back to its original owner. Simultaneously, the term $\underline{t}^{e} \bar{p} i l l \bar{a}$ (or prayer) does not only occur in the final davidic Psalter and is not confined to association with David. After it ceased to be associated with David in Psalm 86, the term is only again linked to David in Psalm 142. Moreover, it should be noted that the term $\underline{t}^{e} \bar{p} i l l a \overline{\text { is }}$ used in Book IV. Here, however, the term is associated with Moses (Ps 90) and an anonymous author (Ps 102). The reason why the reappearance of the terms mas ${ }^{e} k \hat{l} l$ and $t^{e} \bar{p} i l l a \overline{~ i s ~ n o t e w o r t h y ~}$ is the fact that they are employed in the parts of the Psalter (Books I-III) that is associated with the remembrance and celebration of the davidic covenant. In Book IV (the book portraying the exile), the term $\underline{t}^{e} \bar{p} i l l \bar{a}$ is used in reference to Moses. This then serves as an affirmation of the shift in focus from the davidic covenant (Books I-III) to the Sinaitic covenant (Book IV). Through this movement in the Psalter, David is replaced with Moses as the leading figure (Van Grol 2010:312). The reassociation of both the masekil and $\underline{t}^{e} \bar{p} i l l \bar{a}$ with David in the final davidic Psalter (in Book V) points to a new introduction of David. This notion is further strengthened by the use of the interjection (Selah!) that occurs multiple times in the first three books of the Psalter, but fell into disuse from Psalm 89 onwards, just to be revived in Psalm 140:4, 6 and 9 and Psalm 143:6. Only 20 of the davidic psalms use the technical term (Selah!): Psalms 3, 4, 7, 9, 20, 21, 24, 32, 39, 52, 54, 55, 57, 59, 60, 61, 62, 68, 140 and 143 (Briggs 1899:137). The great gap between its final association with David (in Book III) and its current association with David in Psalms 140 and 143 (Book V) serves to illustrate that the final davidic Psalter reintroduces a new David. The reuse of terms that have fallen into disuse, and the reassociation of these terms with the character of David, indicates a systematic revival of the davidic covenant in the shaping of the post-exilic Judean identity. A new character or persona of David comes to the forefront. Who is this new David who is introduced by Psalms 138-145? Van Grol (2010:313) imagined this newly introduced David to resume his role as a leader of the nation; however, his leadership is now confined to prayer. David becomes a prayer leader, who exemplifies subordination through praise and invocation.

Because Psalm 142 includes, what seems to be, a biographical notation about the life of David, it should be considered in our quest to understand the role of David in the final davidic Psalter. Koorevaar (2010:586-588) provided some insight into this topic. Biographical superscripts concerning the life of David are mainly contained in Books I, II and V. When read chronologically, they reveal an inverted biographical history of David. Three key events in the life of David are mentioned to sustain this idea. The first key biographical notation is found in Book I, in Psalm 3:1, which states: 'A psalm of David. When he fled from his son Absalom' (2 Sm 15:13-14).
The second biographical notation is from Book II, in Psalm 51:1, which says: 'For the director of music. A psalm of David. When the prophet Nathan came to him after David had committed adultery with Bathsheba' (2 Sm 11:1-12:25). The third biographical notation is found in Book V, in Psalm 142:1, which states: 'A maskil of David. When he was in the cave. A prayer' (1 Sm 22:1-24:7). When arranging these events on a timeline, it is noticeable that these events are ordered in a manner that reflects the final days of David, which is mentioned first in the Psalter, whilst the early days of David are reflected last in the Psalter. Koorevaar (2010:588) insisted that these events are determinative of the theological climate of the entire Psalter. In a sense, the flight of David and the remembrance of his hiding in the cave serve as a reminder of the fragility of even their most esteemed king. It contrasts the fallibility of man with the omnipotence and omnipresence of YHWH. Although David fled from Saul and hid in a cave, as the reader is reminded in the superscript, the contents of Psalm 142 contradict a 'running away' from something and rather portray a 'running towards' something. Instead of fleeing God, David realises YHWH's authority and supremacy (Ps 139:7-12) and thus wilfully decides to run towards $\mathrm{YHWH}$ and seek hiding in $\mathrm{YHWH}$ by saying: 'I cry to you, O Lord; I say, "You are my refuge, my portion in the land of the living"' (Ps 142:6). In Psalm 142, YHWH becomes the cave (the save and familiar refuge), whilst David is portrayed as the refugee, reminiscent of the time when he was hunted by Saul and was forced to seek hiding in a cave. Here, in the final davidic Psalter, David is again in dire need of aid, fleeing from enemies who surround him. In this instance, however, aid is not presented in the form of a cave, but in the form of divine asylum.

Psalm 144 is the only psalm in the final davidic Psalter that mentions David, not just in its superscript but also in its corpus. Hossfeld and Zenger (2011:586) inferred that the reference to David should not be understood as an allusion to the historical individual, but rather to the multitude of davidic descendants who succeeded the throne over four centuries. An argument can be made that David becomes the representative of the liberated Judeans, mapping the peripheries of their relationship with $\mathrm{YHWH}$, in the new and unknown domain of their post-exilic life. The plea to deliverance from 'the hands of foreigners' (v. 11) would precisely resonate with such a community. As the theme of royalty is again touched upon, our attention is diverted to the title assigned to David. His title in Psalm 144, and the only title afforded to David in the final davidic Psalter, is that עתד [servant] of YHWH. This title serves to illustrate and underline David's humble submissiveness to the divine kingship. Although uplifted and reinstated to the status of king throughout Book V, David's subordination becomes apparent through the use of this designation. Terrien (2003:900) proclaimed the reference to David in verse 5 as 'servant' to be the culmination of an already impressive resumé. The reference to David as 'servant' in Psalm 144 - the only title afforded to David in the final davidic Psalter expounds David's monarchical rule as compliance, not assertiveness. By awarding David this title, the dependence 
of David (as a representative of the post-exilic community) on YHWH is showcased.

Finally, in our exposition to understand the character of David, as he is portrayed in the final davidic Psalter, we are compelled to consider the heading of Psalm 145. In Psalm 145, what is assumed to be the concluding psalm to Book V, we find a heading unparalleled in the Psalter: תהלה לדוד [A song of praise of David]. When considering the superscript of Psalm 145, one must also consider the colon that directly follows this heading. After placing this song of praise in the mouth of David, the psalm follows with the words: 'I will exalt you, my God the King'. Van Grol (2010:320) noted that by adding David's name to the superscript, Psalm 145 is matched with the 'David fiction' of the rest of the collection. However, this time around, the psalm is not at all about the character of David, but solely about YHWH. The only value added by the character of David is the fact that as the anointed king and representative of Israel, he acknowledges $\mathrm{YHWH}$ as King. In the first verse, following the superscript, attention is directed away from David, the earthly king, to YHWH the universal King. Ballhorn (2004:293) saw David's acknowledgement of the kingship of $\mathrm{YHWH}$ as his renunciation of his kingship. Although it is clear that David now accepts YHWH's kingship as greater than his own, there is no reason to suspect that he has now abdicated. In Psalm 145, the reader is only guided to realise the role of the 'new David' under the universal royal rule of God. His role is to be a praise leader - leading the post-exilic community in the acknowledgement of YHWH's kingship as well as their dependence on this kingship and accordingly answering this realisation with commendation. In the final davidic Psalter, David fulfils his role as the priestking by leading the people in worshipping YHWH.

\section{Conclusion}

As Ramantswana (2011:456) noted, the Masoretic Psalter ends on a 'highly davidic' note. The final eight psalms attributed to David command Book V to a climax of the realisation of absolute dependence on YHWH. In a medley of hymnic praises and earnest laments, this theme is achieved. In the final davidic Psalter, David fulfils a twofold purpose. Firstly, David is the one raising an appeal to YHWH's protection against violent and malevolent men. Secondly, he acknowledges his dependence on $\mathrm{YHWH}$, praises $\mathrm{YHWH}$ for it and becomes the facilitator of such praises amongst the devotees of YHWH as well as the pagan nations. Within this framework, David becomes the archetype for an attitude of utmost dependence on YHWH's protection. Through these eight psalms, David once again reveals his subordination to YHWH. This is made evident when we encounter his question to YHWH: 'Lord, what are human beings that you care for them, mere mortals that you think of them?' (Ps 144:3). The theme of subordination should not be seen as contradictory to the foregoing depiction of David's reinstated priestly kingship and the powerful position he is given when he is invited to sit at YHWH's right hand. If anything, the depiction of David's newfound kingship is brought to an apex, when the king (with all his power and might) wilfully submits to the leadership of YHWH.

\section{Acknowledgements Competing interests}

The author declares that they have no financial or personal relationships that may have inappropriately influenced them in writing this article.

\section{Author's contributions}

C.B. is the sole author of this article.

\section{Ethical considerations}

This article followed all ethical standards for research without direct contact with human or animal subjects.

\section{Funding information}

This research received no specific grant from any funding agency in the public, commercial or not-for-profit sectors.

\section{Data availability}

Data sharing is not applicable to this article as no new data were created or analysed in this study.

\section{Disclaimer}

The views and opinions expressed in this article are those of the author and do not necessarily reflect the official policy or position of any affiliated agency of the author.

\section{References}

Ahn, J., 2008, 'Psalm 137: Complex communal laments', Journal of Biblical Literature 127(2), 267-289. https://doi.org/10.2307/25610120

Amzallag, N. \& Yona, S., 2016, 'What does "Maskil” in the heading of a psalm mean?' Ancient Near Eastern Studies 53, 41-57.

Ballhorn, E., 2004, Zum Telos des Psalters: Der Textzusammenhang des Vierten und Fünften Psalmenbuches (Ps 90-150), Philo, Berlin.

Barbiero, G., 2013, 'Psalm 132: A prayer of “Solomon”', The Catholic Biblical Quarterly 75(2), 239-258.

Berlin, A., 2005, 'Psalms and the literature of exile: Psalms 137, 44, 69, and 79', in P.W. Flint \& P.D. Miller (eds.), The Book of Psalms - Composition and reception, pp. 65-86, Koninklijke Brill NV, Leiden.

Briggs, C.A., 1899, 'An inductive study of Selah', Journal of Biblical Literature 18(1/2), 132-143. https://doi.org/10.2307/3268970

Burden, J.J. \& Prinsloo, W.S., 1987, Dialogue with God: Preachers, poets, and philosophers, Tafelberg Uitgewers, Cape Town.

Creach, J.F.D., 1996, Yahweh as refuge and the editing of the Hebrew Psalter, Sheffield Academic Press, Sheffield.

Fraser, J.H., 1984, The authenticity of Psalm titles, Grace Theological Seminary, Portland, OR.

Hossfeld, F.L. \& Zenger, E., 2011, Hermeneia: Psalms 3, Fortress Press, Minneapolis, MN. Howard, D.M., 1993, 'Editorial activity in the Psalter: A state-of-the-field survey', in J.C. McCann (ed.), The shape and shaping of the Psalter, pp. 52-71, Sheffield Academic Press, Sheffield.

Human, D.J., 2009, “"From exile to Zion" - Ethical perspectives from the twin Psalms 127-128', Old Testament Essays 22(1), 63-87.

Jung, W-S., 2016, The Davidic persona in Psalms 138-145 (MT): The movement and development of the portrait of David in the Psalter, Trinity Evangelical Divinity School, Deerfield, IL.

Koorevaar, H., 2010, 'The Psalter as a structured theological story with the aid of subscripts and superscripts', in E. Zenger (ed.), The composition of the Book of Psalms, Uitgeverij Peeters, Leuven.

Longman, T., 2014, Tyndale Old Testament commentaries, Volumes 15-16: Psalms, InterVarsity Press, Downers Grove, IL.

Mays, J.L., 1986, 'The David of the Psalms', Interpretation 40(2), 143-155. https://doi. org/10.1177/002096438604000204 
Mitchell, D.C., 2006, 'Lord, remember David: G.H. Wilson and the message of the Psalter', Vetus Testamentum 56(4), 526-548. https://doi.org/10.1163/156853306778941692

Nogalski, J.D., 2001, 'Reading David in the Psalter: A study in liturgical hermeneutics', Horizons in Biblical Theology 23(1), 168-191. https://doi.org/10.1163/1871220 01X00099

Patton, C.L., 1995, 'Psalm 132: A methodological inquiry', The Catholic Biblical Quarterly 57(4), 643-654.

Prinsloo, G.T.M., 2005, 'The role of space in the twl(mh yryv (Psalms 120-134)', Biblica $86(4), 457-477$.

Ramantswana, H., 2011, 'David of the Psalters: MT Psalter, LXX Psalter and 11QPs Psalter', Old Testament Essays 24(2), 431-463.

Rentdorff, R., 2005, 'The psalms of David: David in the psalms', in P.W. Flint \& P.D. Miller (eds.), The Book of Psalms - Composition and reception, pp. 53-64, Koninklijke Brill NV, Leiden.

Routledge, R., 2009, 'Psalm 110, Melchizedek and David: Blessing (the descendants of) Abraham', Baptistic Theologies 1(2), 1-16.

Sutton, L., 2015, 'A trilogy of war and renewed honour? Psalms 108, 109 and 110 as a literary composition', PhD thesis, Department of Ancient Languages, University of Pretoria.
Tate, M.E., 1990, Word biblical commentary: Psalms 51-100, Word Books, Waco, TX. Terrien, S., 2003, The Psalms: Strophic structure and theological commentary, William B. Eerdmans Publishing Company, Grand Rapids, MI.

Van Grol, H., 2010, 'David and his chasidim: Place and function of Psalms 138-145' in E. Zenger (ed.), The composition of the Book of Psalms, pp. 309-338, Uitgeverij Peeters, Leuven.

Wallace, R.E., 2014, 'Gerald Wilson and the characterization of David in Book 5 of the Psalter', in N.L. DeClaissé-Walford (ed.), The shape and shaping of the Book of Psalms, pp. 193-208, SBL Press, Atlanta, GA.

Wilson, G.H., 1986, 'The use of the Royal Psalms at the "seams" of the Hebrew Psalter', Journal for the study of the Old Testament 35(1986), 85-94. https://doi. org/10.1177/030908928601103505

Wilson, G.H., 2005, 'King, Messiah, and the reign of God - Revisiting the Royal Psalms and the shape of the Psalter', in P.W. Flint \& P.D. Miller (eds.), The Book of Psalms - Composition and reception, pp. 319-406, Koninklijke Brill NV, Leiden.

Zenger, E., 2008, 'Das Buch der Psalmen', in E.E. Zenger, H.-J. Fabry, G. Braulik, G. Hentschel, G. Steins \& H. Engel (eds.), Einleitung in das Alte Testament, pp. 348-370, W Kohlhammer GmbH, Stuttgart. 